\title{
Employability of Accounting TVET Graduates: A Case of One Polytechnic College in Zimbabwe
}

\author{
Chrispen Maireva, Cecilia Muza* and Hessie Beans \\ Great Zimbabwe University \\ *Corresponding Mail: cmuza@gzu.ac.zw
}

\begin{abstract}
Graduate unemployment is one of the biggest challenges that many countries in the world are faced with, more so in Zimbabwe. Given the prevailing rate of unemployment, this study sought to investigate the extent to which the TVET curricula in Accounting has provided sufficient skills to the accounting graduates to meet the expectations for employment. The study sought to deal with the problems that accounting TVET graduates face when entering the job market and the reasons why they are not getting their desired job in their chosen field of study. The study employed a qualitative approach. Data was collected from a sample of five lecturers and 55 Accounting graduates from one Polytechnic college in Zimbabwe, using interviews and a questionnaire. The study found that the main factor contributing to graduate unemployment is the deteriorating economic conditions in the country. It was also found that most of the graduates lacked sufficient skills and work experience to compete in the labor market. The graduates showed general inability to apply knowledge learnt in college to practical work situations, resulting in most graduates struggling to find suitable job placements in the country. It was further established that the graduates were ill-prepared to start their own businesses and did not have access to capital. The study recommends that TVET colleges in Zimbabwe should produce graduates with relevant skills, entrepreneurial mind set and appropriate knowledge acquired through work-based learning and internships to increase chances for employability among the graduates. Financial institutions may also assist through funding the graduates to start entrepreneurial activates in response to limited employment chances.
\end{abstract}

Keywords: Employability, unemployment, employment creation, entrepreneurship, training, TVET education

\section{Introduction}

While graduate unemployment is one of the biggest challenges that many countries in the world are faced with (De Witte, Rothmann \& Jackson, 2012; Kraak, 2015; Oluwajodi et al., 2015), Zimbabwe is no exceptional (Dumbu, 2017; Mafumbate, Gondo \& Mutekwe, 2014, Mwenje, 2016). As a result, there is always an intense competition for jobs in the employment market, particularly in the accounting field. Generally, attributes that influence the unemployment rates among graduates from Technical and Vocational Education and Training (TVET) Colleges and Universities are related to low economic growth-employment elasticity, minimum wages and labor market rigidities, opportunity costs of employment, overly protective labor laws, and structural imbalances in the supply of and demand for skilled potential employees (Uddin \& Uddin, 2013; Van Aardt, 2012; and Yu, 2013). However, while achievement of good academic qualifications is highly valued, it no longer appears sufficient to secure employment in the accounting profession.

Van Aardt (2012) argues that the persistently high rate of unemployment among recent graduates is attributed to their area of residence, age, economic environment, ethnicity, skills levels and qualifications. Extant literature also shows that graduate unemployment can be attributed to similar characteristics to general and youth unemployment contributors (Kraak, 2015; Van Aardt, 2012). It is difficult for graduates to get jobs because most of the graduates lack sufficient skills and work experience to compete in the labor market (De Witte, et al., 2012; Mwenje, 2016).

Consequently, demand for TVET is increasing worldwide and Zimbabwe is included (Arfo, 2015; UNESCO, 2013). Limited TVET has led to lack of 
employment opportunities; hence the university and college graduates are forced to indulge in both legal and illegal activities to irk out a living. It is, therefore, the duty of institutions of higher learning to bridge this gap in the education system for socioeconomic and sustainable development. Thus, entrepreneurship is seen a potential solution to integrate the young TVET graduates into the global economy and labor market (Ama, 2008). In addition, graduate entrepreneurship is beneficial to the young graduates and the society at large, as it creates more employment opportunities for other economically active youths (Green, 2013). Entrepreneurship also increases innovation and creativity among young graduates as well as raising competition. Uddin and Uddin (2013) argue that innovation, creativity and competition contribute to the economy of the country.

Employability is defined as a set of achievements skills, qualities, knowledge, understandings, experiences and personal attributes that make graduates more likely to gain employment and be successful in their chosen occupations, which benefits themselves, the workforce, the community, and the country's economy (Bhorat, Mayet and Visser, 2012; Edayi, 2016; Yorke, 2006). Pool (2017) defines employability as a set of personal characteristics, experiences, talents, and thoughtfulness that distinguishes an individual, or makes that individual more likely to choose and secure a job in which they can be fulfilled and successful. Thus, this study defines employability as the personal attributes and characteristics that jobseekers should possess to guarantee that they have the competence to be productive in the workplace. Graduate employability can only be achieved through producing graduates with practical and basic skills (Rogan \& Reynolds, 2016; Hamilton et al., 2015). The rationale is that graduates need to be well-prepared and are expected to have certain generic or self-attributed qualities.

The Australian Chamber of Commerce and Industry developed a framework of employability skills as perceived by industries. These included the key competencies such as teamwork and communication as well as problem solving and technical skills. It also identified self-management, learning, initiative, enterprise and personal attributes such as loyalty, integrity and sense of humor, to name just a few as important attributes that graduates should possess. Similar research on employability skills has likewise been undertaken by the Mayer Committee set up by the Australian Education Council; the British National Skills Task Force; the Secretary's Commission on Achieving Necessary Skills (SCANS) in the United States and the Conference Board of Canada (Jackson, 2013; Mhlongo, 2020).

Employability skills are needed by students to prepare themselves to meet the needs of many different occupations after graduation. Employability skills are the basic skills necessary for getting, keeping and doing well on a job and these can be divided into three categories: basic academic skills, higher order thinking skills and personal qualities (Cranmer, 2006). These skills are necessary for career success. Employers today are concerned about finding good employees who not only have basic academic skills like reading, writing, science, mathematics, oral communication and listening, but also higher order thinking skills like learning, reasoning, thinking creatively, decision making and problem solving (Saunders \& Zuzel, 2010). They also look for employees that have personal qualities that include responsibility, self-confidence, self-control, social skill, honesty, integrity, adaptability, flexibility, team spirit, punctuality, efficiency, self-direction, good work attitude, cooperation, self-motivation, and self-management (York, 2006).

However, several studies such as Cassidy and Wright (2008); Graham and Mlatsheni (2015); Kraak (2015); Oluwajodu et al. (2015); Uddin and Uddin (2013); and $\mathrm{Yu}$ (2013) have shown that there are some attributes that are specific and unique to graduate unemployment. These attributes include the general economic environment and the economic outlook, expectations of the graduates in respect of finding employment and the mismatch between the skills possessed by graduates and those expected and required by employers on the job.

On the other hand, Vinichenko et al. (2016) argue that employers tend to assume that recent graduates from TVET universities and colleges may be incompetent. The assumption is prevalent among senior executives as Hart and Barratt (2009) show in their study in the United Kingdom (UK), that senior executives in ICT organizations often refuse to employ graduates. It was found that the main reasons why senior executives do not want to employ new graduates include cultural and communication barriers, which may be attributed to the senior executives' previous experiences with unskilled graduates. 
Given the rapid expansion of universities and colleges enrolment the world over, it was found that the labor market has limited capacity to absorb all graduates upon graduation (Coetzee \& Esterhuizen, 2010; Oluwajodi, et al., 2015; Uddin \& Uddin, 2013). Resultantly, the supply of qualified and educated graduates has exceeded the demand for skilled labor in most economies of the world. In most economies in the world, weak and limited economic growth prospects have curtailed economies' ability to absorb the large number of graduates (Anyanwu, 2000; Uddin \& Uddin, 2013). This has resulted in a shift by the labor market towards highly skilled, technologically advanced, and highly productive labor force (Oluwajodi et al., 2015).

Mhlongo (2020) argues that accounting is one of the study areas which are selected by students because of the perceived ability by accounting graduates to secure immediate employment. Jeacle (2008) contends that the accounting field is one of the areas that have grown in popularity among school leavers in recent years, despite the perception by some that it is tedious, uninteresting and lesscreative, and thus meant for the conservative. Several studies such as Abayadeera and Watty (2014); Aman and Sitotaw (2014); Seetha (2014) and Tan and Fawzi (2017) showed that employers prefer skilled accounting graduates with generic (or soft) skills who are ready to add value in the workplace.

Globally, accounting literature has used various terms when referring to employability skills and qualities; these include professional skills (International Federation of Accountants, 2014), generic skills (Bunney et al., 2015), soft skills (de Villiers, 2010), and many others. However, concerns have been raised by employers about the employability and work readiness of accounting graduates, mainly due to their lack of employability skills and qualities (Kunz \& de Jager, 2019). That is, there is a gap between what employers expect and prefer and what the accounting graduates possess. Mhlongo (2020) identified the following 15 skills as important for accounting graduates to have. These are: self-management, time management, selfdiscipline, independence, oral communication, written communication, critical thinking, decision making, computer application, teamwork, stress management, problem solving, lifelong learning, responsibility, numeracy.

In accounting, Tempone et al., (2012) argue that there is evidence which suggest that accounting graduates face challenges with the application of theoretical knowledge they got at the university or college to practical workplace situations. Wye and Lim (2009) further postulate that graduates were unable to adapt to the workplace because of their poor command of employability skills and qualities. Some studies, such as Hakim (2016) and Mohamed and Lashine (2003), attribute these challenges to the inadequacy (or failure) of the accounting curriculum at institutions of higher learning to produce graduates who are adequately prepared and are ready for professional practice. Resultantly, Cory and Pruske (2012) argue that several scholarly debates have been done on the abilities and deficiencies of the accounting education curriculum in producing graduates who meet the expectations of employers.

Graduate unemployment is further caused by the mistaken belief among graduates that acquiring a university or college qualification, without acquiring other relevant skills for the workplace, is sufficient for acquiring employment (Oluwajodi et al., 2015; Sithole, 2015; Van Schalkwyk \& Surujlal, 2012). Van Aardt (2012, p. 60) argues that, "schooling is not a reliable indicator of capabilities, and low school quality feeds into poor workplace learning capacity". Therefore, acquiring a university or college qualification does not in itself guarantee employment. Instead, it is only one step closer for graduates to obtaining employment. Thus, this suggests that accounting TVET programmes from the various colleges and universities are not producing sufficiently skilled graduates for employability. It therefore indicates that there is no proper alignment between students, universities, and employers in relation to viable feedback about employers' expectations and requirements for employability.

Vinichenko, et al. (2016) argue that talented graduates encounter challenges of a strict staff recruitment system due to its selection and assessment criteria that employers apply in terms of the work experience required from graduates. They further claim that most employers are not ready to spend time and money on training young accounting professionals. In addition, some employers have probably had negative experiences when employing unskilled graduates from colleges or universities.

The current trend whereby employers increasingly emphasize on, and demand, employability skills and qualities from graduates, therefore, dictates that the TVET accounting education curriculum should incorporate opportunities to develop the expected 
employability skills in conjunction with a subjectspecific skills and knowledge (Kunz \& de Jager, 2019; Mhlongo, 2020; Tan \& Fawzi, 2017). To this end, different academic programs in different universities and polytechnic colleges have various strategies, for example, offering work experience, work-related learning and employability skills modules, and readiness for work, as well as involving employers in course design and delivery.

Thus, the main purpose of this study was twofold, to investigate the extent to which the accounting TVET curricula has provided sufficient skills set and qualities to the accounting graduates to meet employer needs, criteria and expectations for employment and to analyze whether the accounting TVET curriculum was geared to provide entrepreneurial skills necessary to enable graduate to create employment for themselves and other young graduates. The study was guided by the following research question:

1. To what extent does the accounting TVET curriculum provide sufficient skills for employability for accounting graduates?

2. What are challenges faced by TVET Accounting Graduates in the labor market?
3. Was the accounting TVET curriculum geared to provide entrepreneurial skills for employment creation?

\section{Research Methodology}

The study employed a qualitative approach as a strategy for data collection, analysis and interpretation. This was motivated by the need to understand the issues affecting accounting graduate employability. A phenomenological research design underpinned the study, given the need to clearly investigate and establish the employability of accounting TVET graduates. Phenomenology allows for the study to focus on a particular phenomenon, collect data through in-depth interviews with participants with the objective of gaining some insight into their world and to describe their perceptions and reactions, and then identify what is common to their perceptions (Fraenkel, Wallen \& Hyun, 2011).

\section{Population and Sampling}

The population of the study comprised 275 accounting graduates from one polytechnic college in Zimbabwe who graduated with National Diplomas and Higher National Diplomas in Accountancy in the year 2019. It was also made up of 15 lecturers in the Department of Accountancy at the polytechnic college.

Table 1: Population and sample of the study

\begin{tabular}{l|cc}
\hline \multicolumn{1}{c}{ Participants } & Population & Sample \\
\hline Accountancy lecturers & 15 & 5 \\
Accounting graduates & 275 & 55 \\
Totals & 290 & 60 \\
\hline
\end{tabular}

A sample of 60 participants was drawn from the population. The sample comprised of five lecturers and 55 TVET accounting graduates. The study employed a convenience sampling technique based on the alumni association database of the Polytechnic College. Lecturers who took part in the study were also conveniently selected to be part of the sample. The rationale for this approach was ease of access to information and availability of data collectors based on the selected institution. The information is depicted in table 1 :

\section{Instrumentation}

The study made use of the questionnaire and interview schedule to collect data on the employability of accounting TVET graduates. The questionnaire was open-ended. The researchers chose to use the open-ended questionnaire for the collection of data because it is effective and efficient for the kind of information required from a relatively large sample of accounting graduates. Indepth, telephonic interviews were also conducted with college lecturers. The interview guide was used during the telephonic interview schedule to maintain consistence to different participants. This helped in maintaining chronology and the flow of information in the interview process.

\section{Data Analysis}

Data from the questionnaires and interviews were analysed using a thematic approach. The themes were drawn from the research questions and the responses from the study participants.

\section{Ethical Considerations}

In carrying out this study, several ethical considerations were observed. The informed consent of the participants was sought and obtained before the study was conducted. The participants 
were also informed of the voluntary nature of the study and they were informed that they were free to participate or withdraw from participating in the study at any time.

\section{Discussion and findings}

The study sought to investigate the extent to which the TVET curricula in Accounting has provided sufficient skill set and quality to the accounting graduates to meet the employer needs, criteria and expectations for employment.

The study also sought to unravel the problems that accounting TVET graduates face when entering the job market and the reasons why they are not getting their desired job in their chosen field of study. In addition, the researchers sought to find out if the graduates were equipped with entrepreneurial skills that they could use to start and run their own businesses and create jobs for themselves and other graduates.

This section presents the results obtained from the empirical study, based on the themes that came out from the self-administered, open-ended questionnaires and telephonic interviews with accounting TVET graduates and accountancy lecturers, respectively, from one polytechnic college in Zimbabwe. The themes were drawn from the research questions.

Research Question 1: To what extent does the accounting TVET curriculum provide sufficient skills for employability for accounting graduates?

The study found that there was a gap in the curriculum offered by TVET colleges and universities and the skills and competences that the employers expected the TVET accounting graduates to possess for them to be employed. From the findings it was indicated that for graduates to be successful in the labor markets, they needed skills which could not be developed in the classroom. Thus, there was need to have a clear understanding of the necessary skills which need to be incorporated into the accounting curriculum to ensure easy absorption of accounting graduates into the accounting profession.

It was found that there is a very wide gap between accounting TVET curricula and the industrial expectations. The study found that the accounting curriculum was limited to imparting technical skills, number-crunching and following the guidelines of the International Financial Reporting Standards (IFRS) and International Accounting Standards (IAS). No deliberate effort was made to teach the generic skills that were found to be important such as selfand time management, computer applications and oral communication skills. With the evolving world which is technologically driven, TVET accounting graduates were expected to be creative with personal attributes like problem-solving skill, ethics, being innovative and being able to update their knowledge and expertise. They also need to have self-improvement skills like motivation, self-worth, and confidence. It was highlighted that in many economies, employers seek for employees with behavioral skills such as creativity, teamwork, entrepreneurship and diligence. . Furthermore, enterprise, negotiation and adaptability are becoming necessary skills for employability suggesting that these competences have a fundamental role to play in creating employable graduates (World Bank, 2010). This finding concurs with the views of Maclean and Lai (2011) who found that the curriculum offered in most TVET colleges and universities did not align with imparting the necessary skills that were needed by the industry.

However, the above finding was inconsistent with that of Abdulkadir (2011) who conducted a study in Nigeria and found that accounting graduates were prepared for knowledge acquisition which was relevant to employment in typical existing business enterprises. This can be explained by the fact that graduates from professional accounting courses were equipped with the necessary skills needed by industry to be able to fit into the workplace. This is because some professional accounting bodies such as the Association of Certified Chartered Accountants (ACCA), Chartered Institute of Management Accountants (CIMA) and the Institute of Chartered Accountants (Zimbabwe) (ICAZ) have entered into agreements with some universities to offer their accounting courses. These professional accounting bodies emphasize on the acquisition of technical skills, practical work experience and professional ethics as the core skills and competences expected of university graduates. In the case of the polytechnic college under study, no such agreement was in place. Therefore, it was found that the college continued to offer an academic and theoretical curriculum which was not in line with the professional skills needed for the accounting TVET graduates to be equipped with for their employability.

By its nature, accounting is a vocation-based qualification. For an accounting education program to be relevant, it has to offer practical acquisition 
and application of skills and abilities in order to equip graduates for real life situations. Therefore, if the curriculum failed in this respect, the graduates would find it difficult to be absorbed by the labor market. Thus, it was found that there were inconsistences in the accounting TVET curriculum and the needs of the employers. This implies that employers needed the learning institutions to spend additional resources in training and development of future staff, who are expected to be well-equipped with the relevant skills to allow the them to be integrated into the labor force.

When it comes to the TVET curricula offered by the college, it was revealed by the participants that there was need for curriculum reforms with the aim of improving competences of the graduates and modernizing the programs to reflect serviceoriented markets and the need of modern society. The college was found to be striving to improve its accounting department's curriculum to provide quality and relevant education.

The study further revealed that creating fully furnished graduates with theoretical knowledge was not effective. It was found that the accounting graduates needed to have multi-disciplinary skills which are applicable in practice. It was further found that lack of practical aspects in the accounting course content alienated students from the accounting profession, thereby making it difficult for new graduates to enter the labor market. The situation found in this study is similar to what Singh (2004) found in a study in India that accounting education failed to meet the changing nature of business in an evaluation of the courses offered by professional bodies and colleges.

For TVET accounting graduates to be employable, responses from both the lecturers and the graduates themselves indicated that accounting students in colleges need the generic (employability) skills when entering the workplace. Thus, it was found necessary to determine the extent to which current teaching methodologies address the development of the required skills from accountants. As has been suggested by Bui and Porter (2010), accounting programs are not in harmony with the requirements of the real world and fail to meet the expectations of the employers. The study revealed that for professional accountants to perform effectively, they need professional skills like interpersonal and communication, organizational, personal and intellectual. Another fact raised by the participants in relation to the accounting TVET curriculum and the expectations of employers was of the accounting educators themselves. It was found that some of the accounting educators lacked the practical experience in the accounting field, especially those who started off their careers with academic institutions ending up being instructors for most of their careers.

It was found that accounting educators with the opportunity of having gained practical experience and therefore having the exposure to the real-world of accounting were those who joined the academics from the industry. Hence, accounting educators with previous practical experience were found to better understand the skills needed by the accounting graduates. This finding corroborated the findings by Mgaya and Kitindi (2009) who confirmed that accounting educators in Botswana are failing to produce graduates with essential skills due to lack of practical experience. UNESCO (2009) encouraged employers and the industry to be involved in the TVET service delivery and teacher training through public-private partnership with TVET institutions and government.

Research Question 2: What are challenges faced by TVET Accounting Graduates in the labor market?

Given the shortcomings of the curriculum offered by TVET colleges and expectations of the labor market in terms of the needed skills for employability, the study found that accounting TVET graduates faced several challenges when they enter the labor market. It was revealed in the study that professional accountants are the front runners and key pillar in the business since they help to sustain the value and growth of organizations trusted with financial information. Thus, they needed to be sufficiently skilled and experienced to take up such an important task in any organization. Therefore, new graduates faced the hurdle of having insufficient skills and experience to handle the finances and other resources of the business.

The lecturers indicated that they expected employers to require written communication such as report writing, computing techniques and reporting skills. In contrast, those graduates that were fortunate enough to find work indicated that employers expected accounting students to be highly skilled in research, measurement, and reporting skills. The findings of the study are consistent with Jones (2011) who argued that 
written communication skills such as writing clearly and spelling correctly; preparing concise, accurate and supportive documents; documenting work completely and accurately; effectively using email; and conscientiously editing and revising documents as the most important required skills by the employer. In a study by Sithole (2015), it was found that accounting graduates were expected by the employers to be more knowledgeable and competent with accounting packages and spreadsheets and when dealing with technological skills, they indicated that competence in world processing, software skills and communication skills were essential aspects.

The study also revealed that some accounting graduates did not possess the relevant basic accounting skills as they were not self-confident when taking practical decisions and could not solve problems on their own. For effective performance by accounting graduates, the industry required the graduates to have full the understanding of tax return preparation, financial transaction, computerized accounting system, fund accounting knowledge, quantitative analysis, cost accounting skills and audit and assurance competence. It was found that good basic accounting skills in critical and analytical thinking, teamwork, communication and technology gives higher satisfaction to employers and transforms accounting profession in future Thus, the accounting TVET graduates did not have those skills thereby presenting challenges to employers who had to retrain the graduates for them to fit into the world of work. But the main challenge with TVET graduates is that they are deficient in some generic skills and experience needed in their field for actual work practice and they are also affected by their curriculum and economic factors. These problems affect the employability of accounting graduates causing them to be considered as poor quality by employers.

The study participants indicated that their ability to continue fulfilling their roles in the constantly changing business environment was very vital for them to be relevant. The study also found that the prospects of accounting TVET graduates to be employed were curtailed by the economic prospects of the country. Most of the employment was found in the informal sector. According to Zimstats (2020) almost $90 \%$ of the employed population in the country is employed in the informal sector. Formal employment only accounts for $10 \%$ of the employed population. Given the level of economic activity in the country, there are generally limited employment opportunities in the country. In the case in point, it was found that the country was experiencing a high formal unemployment rate. This also affected the accounting TVET graduates given that there were limited job opportunities in the labor market. This finding concurred with the findings by Uddin and Uddin (2013) in a study that was conducted in Nigeria where it was found that the economic growth prospects had an impact on the employability of graduates. The findings also confirm similar findings by Van Aardt (2012) who conducted a review of youth unemployment in South Africa over a seven-year period from 2004 to 2011.

The participants also indicated that the employment elasticity affected the chances of the accounting TVET graduates. It was found that there was limited supply of jobs given a very high demand from graduates from other universities. The study found that in addition to the technical colleges and universities of science and technology, there were several other academic universities that produced more accounting graduates, thereby flooding the market. Given the level of economic activity, the labor market is very elastic, and the employers are spoilt for choice. Thus, this brings a lot of competition among graduates to do better than the rest. This finding agrees with the findings by $\mathrm{Yu}$ (2013) who found that employment elasticity was a challenge in the employability of graduates in general. Considering the increase in universities and colleges, Anyanwu (2000) found that the supply of qualified and educated graduates has outsprinted the demand for skilled labor in most economies of the world, thereby curtailing the ability of most countries to absorb the large number of graduates from the expanded university and college enrolments. Accordingly, the labor market now demands highly skilled, technologically advanced, and highly productive labor force (Oluwajodi et al., 2015).

The elasticity of the job market was further compounded by the labor market rigidities whereby, the graduates were unable to secure employment because of limited job opportunities and demand for work experience from recent graduates who did not have experience. While it was found that all the accounting TVET programs had a requirement for a period of work placement (or industrial attachment), the work experience that the graduates had was insufficient when compared 
with experienced employees considering competition for the very few job opportunities available due the economic conditions of the country. The findings of the study agree with the assertions by Kraak (2015), in a study in South Africa who found that work experience was a key consideration by most employers when selecting candidates to fill vacancies.

Research Question3: Was the accounting TVET curriculum geared to provide entrepreneurial skills for employment creation?

The data revealed that the graduates lacked necessary entrepreneurship skills, most importantly the accounting, business and marketing skills to start up and sustain their own businesses. Most companies closed throughout the country because of the economic hardships that the country is experiencing in face of the inflationary pressures, which were exacerbated by the Covid-19 pandemic. Thus, the accounting graduates found it difficult to get employed or secure the market for their small businesses.

As much as accounting TVET graduates need to be employed, their programs need to have some characteristics which will prepare the graduates to become self-employed, functioning independently and running their own businesses even when they are not employed. The study established a general perception among young people that a university or college qualification is the only means to obtain employment in the labor market and to sustain one's livelihood. Thus, entrepreneurship is a potential solution to integrate the young TVET graduates into the global economy and labor market (Ama, 2008).

In addition, graduate entrepreneurship is beneficial to the young graduates, and the society at large, as it creates more employment opportunities for the youths (Green, 2013). Entrepreneurship also increases innovation and creativity among young graduates as well as raising competition and thus, the economic growth (Uddin and Uddin, 2013).

The study further revealed that there was stiff competition as some accounting students had graduated from local and international universities, giving great challenges to those from colleges. It was found that the accounting graduates from local and international universities had experienced training in the professional ethics and practical requirements from their academic programs. Therefore, while accounting TVET graduates may have the vocational and technical skills, they may need practical experience to enable them to be able to fully offer accounting and tax services to other small business.

\section{Conclusion and Recommendations}

Based on the findings, the following are conclusions and recommendations of the study.

\section{Conclusions}

The study concluded that the accounting TVET graduates failed to find employment in line with their field of study because they did not have sufficient employability skills that are necessary for success in the job market. Failure to get employment was partly occasioned by the expectations of the employers which were not met by the TVET curriculum. The elasticity of the labor market, lack of work experience by the graduates and the general economic conditions prevailing in the country were major hindrances for college graduates to get employed.

\section{Recommendations}

The study recommends that TVET colleges in Zimbabwe should produce graduates with relevant skills, entrepreneurial mind set and appropriate knowledge acquired through work-based learning and internships to increase chances for employability among the graduates. Financial institutions may also assist through funding the graduates to start entrepreneurial activates in response to limited employment chances.

Through joint curriculum development, collaboration between colleges and the industry is recommended to improve the quality of education and training given to TVET accounting graduates. This will enable colleges to incorporate necessary aspects which are expected by the employers since they are the end users of these graduates.

Finally, accounting educators and professionals need to be aware of the need to revise the curricula regularly. When designing the syllabus, there is need to align and cover practical aspects as required by the job market.

\section{Reference}

Abayadeera, N., \& Watty, K. (2014). The expectation performance gap in generic skills in accounting graduates: Evidence from Sri Lanka. Asian Review of Accounting, 22(1), 56-72. 
Abdulkadir, A. A. (2011). The role of entrepreneurship education in empowering Nigerian youths. Business Education Journal, 8 (1), 14-22.

Ama, N. O. (2008). Transition from higher education to employment: A case study of graduates of faculty of Social Sciences University of Botswana. Educational Research and Review, 3(8), 262-274.

Aman, M., \& Sitotaw, M. (2014). Perception of summer cooperative graduates on employersgeneric skills preference, Haramaya University, Ethiopia. International Journal of Instruction, 7(2), 181-190.

Anyanwu, G. A. (2000). Graduates' Transition from study to employment: A study of the Arts and Agriculture graduates of University of Nigeria in the World of Work. Department of Home Science and Nutrition.

Arfo, E. B. (2015). A comparative analysis of technical and vocational education and training policy in selected African countries. PhD Thesis, University of KwaZulu-Natal Durban.

Bhorat, H., Mayet, N. and M. Visser. 2012. Student Graduation, Labour Market Destinations and Employment Earnings. DPRU Working Paper 12/153. Cape Town: Development Policy Research Unit.

Bui, B., \& Porter, B. (2010). The expectationperformance gap in accounting education: An exploratory study. Accounting Education: An International Journal, 19, 23-50.

Bunney, D., Sharplin, E., \& Howitt, C. (2015). Generic skills for graduate accountants: The bigger picture, a social and economic imperative in the new knowledge economy. Higher Education Research \& Development, 34(2), 256-269.

Cassidy, T., \& Wright, L. (2008). Graduate employment status and health: A longitudinal analysis of the transition from student. Social Psychology of Education, 11(2), 181-191.

Coetzee, M., \& Esterhuizen, R. (2010). Psychological career resources of the young unemployment African Graduate: An exploratory study. South African Journal of Industrial Psychology, 36(1), 1-9.
Cory, S. N., \& Pruske, K. A. (2012). Necessary skills for accounting graduates: An exploratory study to determine what the profession wants. ASBBS Proceedings, 19(1), 208-218.

Cranmer, S (2006). Enhancing Graduate Employability: Best Intentions and Mixed Outcomes. Studies in Higher Education 31:169-184. DOI: 10.1080/030 75070600572041.

de Villiers, R. (2010). The incorporation of soft skills into accounting curricula: Preparing accounting graduates for their unpredictable futures. Meditari Accountancy Research, 18(2), 1-22.

De Witte, H., Rothmann, S., \& Jackson, L, T. B. (2012). The psychological consequences of unemployment in South Africa. South African Journal of Economic and Management Sciences, 15(3), 235-252.

Dumbu, E. (2017). Entrepreneurial strategies for dealing with unemployment challenges employed by the graduate youths in Masvingo Urban. Journal of Studies in Social Sciences and Humanities Volume 3, No. 4, 2017, 109-117.

Edayi, J. (2016). Constraints to graduate employment in the City of Johannesburg, South Africa. Thesis (M.Com. (Management)) - University of the Witwatersrand, Faculty of Commerce, Law and Management, School of Economic and Business Sciences, 2016.

Fraenkel, J. R.; Wallen, N. E.; Hyun, H, H. (2011). How to Design and Evaluate Research in Education, (Eighth Edition). New York: McGraw-Hill Companies, Inc.

Graham, L., \& Mlatsheni, C. (2015). Youth Unemployment in South Africa: Understanding the challenge and working on solutions. South African Child Gauge, 5159.

Green, F. (2013). Youth entrepreneurship: $A$ background paper for the OECD Centre for Entrepreneurship, SMEs and Local Development. OECD publication.

Hakim, R. R. C. (2016). Are accounting graduates prepared for their careers? A comparison of employees' and employers' perceptions. 
Global Review of Accounting and Finance, 7(2), 1-17.

Hamilton, M., Carbone, A., Gonsalvez, C. \& Jollands, M. (2015) Breakfast with ICT employers:

What do they want to see in our graduates. Proceedings of the $17^{\text {th }}$ Australasian

Computing Education Conference (ACE 2015) 27(1) pp.29-36.

Hart, T. \& Barratt, P. (2009) The employment of graduates within small and medium sized firms in England. People, Place and Policy Online 3(1) pp.1-15.

Jackson, D. (2013). Business graduate employability: Where are we going wrong? Higher Education Research \& Development, 32(5), 776-790.

Jeacle, I. (2008). Beyond the boring grey: The construction of the colourful accountant. Critical Perspectives on Accounting, 19(8), 1296-1320.

Jones, C. G. (2011). Written and computer-mediated accounting communication skills: Employer perspective. Business Communication Quarterly 74: 247-271.

Kraak, A. (2005). The value of graduate destination survey data in understanding graduate unemployment: A focus on University of Technology. South African Journal of Labour Relations, 39(1), 93-113.

Kunz, R., \& de Jager, H. (2019). Performance of newly employed trainee accountants in Gauteng, South Africa, versus the skills expectations of employers: How big is the gap? Industry and Higher Education, 33(5), 340-349.

Maclean, R., \& Lai, A. (2011). Future of Technical and Vocational Education and Training Global Challenges and Possibilities. International Journal of Training Research, 9, 2-15.

Mafumbate, R., Gondo, T., \& Mutekwe, E. (2014). Graduate Employment Challenges in Zimbabwe: A Case of Zimbabwe Open University Graduates. Journal of Education and Practice, Vol.5, No.20, pp 57-63.

Mgaya, K. V. \& Kitindi, E. G. (2009). Essential skills needed by accounting graduates in a developing country: the views of practising accountants and accounting educators in Botswana. International Journal of Accounting, Auditing and Performance Evaluation (IJAAPE), Vol. 5, No. 3, 2009.

Mhlongo, F. (2020). Pervasive skills and accounting graduates' employment prospects: Are South African employers calling for pervasive skills when recruiting? Journal of Education, 2020, Issue 80, pp 50-71.

Mohamed, E. K., \& Lashine, S. H. (2003). Accounting knowledge and skills and the challenges of a global business environment. Managerial finance, 29(7), 3-16.

Mwenje, S. (2016). The Challenge of Graduate Unemployment: A Case of University Graduates in the City of Mutare- Zimbabwe. International Journal of Innovative Social Sciences \& Humanities Research 4(4):50-57, Oct.-Dec. 2016.

Oluwajodu, F., Blaauw, D., Greyling, L., \& Kleynhans, E. P. J. (2015). Graduate unemployment in South Africa: Perspectives from the banking sector. South African Journal of Human Resources Management, 13(1), 1-9.

Pool, L,D. (2007). The key to employability. Developing a practical model of graduate employability. Centre for Employability, University of Central Lancashire, Preston, UK

Rogan, M., and J. Reynolds. (2016). Schooling Inequality, Higher Education and the Labour Market: Evidence from a Graduate Tracer Study in the Eastern Cape, South Africa. Development Southern Africa 33 (3): 34360.

Saunders, V \& Zuzel, K. (2010). Evaluating Employability Skills: Employer and Student Perceptions. Bioscience Education eJournal 15(1), DOI: 10.3108/beej.15.2.

Seetha, N. (2014). Are soft skills important in the workplace? A preliminary investigation in Malaysia. International Journal of Academic Research in Business and Social Sciences, $4(4), 44-56$.

Singh, G. (2004). Emerging Dimensions of Accounting Education and Research in India, Vol. 10 No.22 (2004): 24. 
Tan, L. M., \& Fawzi, L. (2017). Employability skills required of accountants. SHS Web of Conferences 34, 06001. http://doi.org/10.1051/shsconf/201734060 01.

Sithole, T. S. M. (2015). Quality in accounting graduates - employer expectations of the graduate skills in the Bachelor of Accounting degree. European Scientific Journal August 2015 Edition Vol.11, No.22 ISSN: 1857- 7881 (Print) e - ISSN 1857- 7431.

Tempone, I., Kavanagh, M., Segal, N., Hancock, P., Howieson, B., \& Kent, J. (2012). Desirable generic attributes for accounting graduates into the twenty-first century. Accounting Research Journal, 25(1), 41-55.

Uddin, P. S. O., \& Uddin, O. O. (2013). Causes, effects, and solutions to youth unemployment problems in Nigeria. Journal of Emerging Trends in Economics and Management Sciences, 4(4), 397-402.

UNESCO-UNIVOC Regional Forum. (2013). Advancing TVET for youth employability and sustainable development. In Meeting Report (pp. 1 - 32).

Van Aardt, I. (2012). A review of youth unemployment in South Africa, 2004 to 2011. South African Journal of Labour Relations, 36(1), 54-68.
Van Schalkwyk, P., Niyimbanira, F., \& Surujlal, J. (2012). Transition from graduation to employment: A qualitative exploration of Sport Management graduates' experiences. African Journal of Physical, Health Education, Recreation and Dance, 18(1), 214-226.

Vinichenko, M. V., Makushkin, S. A., Melnichuk, A.V., Frolova, E. V. \& Kurbakova, S. N. (2016) Student employment during college studies and after career start. International Reviewof Management and Marketing 6(5S) pp.23-29.

World Bank (2010). Stepping up skills for more jobs and higher productivity. Washington, D.C. Learning, 13 - 28.

Wye, C.-K., \& Lim, Y. M. (2009). Perception differential between employers and undergraduates on the importance of employability skills. International Education Studies, 2(1), 95-105.

Yorke, M. (2006). Employability in Higher Education: What it is-What it is not. Learning andEmployability Series One, Higher Education Academy, York.

Yu, D. (2013). Youth unemployment in South Africa since 2000 revisited. Documents de trabajo economico, 4(13), 1-17. 